\title{
Pengaruh Kepatuhan Diet Pada Pasien Gagal Ginjal Kronis di Unit Hemodialisa Rumah Sakit Sumber Waras
}

\author{
Cicielia Ernawati Rahayu
}

\author{
Akademi Keperawatan Sumber Waras Jakarta \\ r.cicilia21@yahoo.co.id
}

\begin{abstract}
ABSTRAK
Gagal ginjal kronis (GGK) merupakan suatu sindrom klinis yang disebabkan gangguan fungsi ginjal yang yang bersifat menahun, berlangsung progresif dan irreversible, Penatalaksanan pasien GGK tahap akhir selain dilakukan tindakan hemodialisa, diet dan pembatasan cairan., yang berlangsung terus menerus dan membutuhkan kepatuhan bagi pasien. Tujuan penelitian untuk mengetahui faktor-faktor yang berhubungan dengan kepatuhan diet pada pasien GGK di RS Sumber Waras. Metode penelitian deskriptif analitik dengan ujisatatisik Chi Square dengan tingkat kemaknaan 95\% yang meliputi analisa univariat maupun bivariat. Hasil penelitian didapatkan 72,5\% responden tidak patuh terutama pada pasien yang hemodialisa lebih dari 6 bulan. Hasil analisa Chi Square terbukti ada pengaruh pengetahuan terhadap kepatuhan diet padapasiengagalginjalkronissecarabermakna $(\mathrm{p} 0,006)$. Ada pengaruh lamanya menjalani terapi hemodialisa terhadap kepatuhan diet pada pasien gagal ginjal kronis secara bermakna (p0,00). Kesimpulan kepatuhan diet pada pasien gagal ginjal kronis secara bermakna, dengan pengetahuan dan lamanya responden menjalani tindakan hemodialisa. Rekomendasi perlu dilakukan penelitian lanjutan mengenai faktor- faktor yang dapat meningkatkan kepatuhan pasien terhadap diet, terapi cairan maupun hemodialisa.
\end{abstract}

Kata Kunci: Kepatuhan Diet, Gagal Ginjal Kronis, Hemodialisa

\section{PENDAHULUAN}

Ginjal merupakan organ tubuh yang berperan penting dalam mempertahankan kestabilan lingkungan dalam tubuh dan kelangsungan hidup dan fungsi sel secara normal bergantung pada pemeliharan konsentrasi garam, asam dan elektrolit lain dilingkungan cairan internal. Apabila kerusakan ginjal terjadi secara menahun dapat menyebabkan terjadinya gagal ginjal kronis.

Gagal ginjal kronis (GGK) merupakan suatu sindrom klinis yang disebabkan gangguan fungsi ginjal yang bersifat menahun, berlangsung progresif dan bersifat irreversible yang memerlukan tindakan hemodialisa, pengaturan diet dan cairan yang masuk

Indonesia termasuk Negara dengan jumlah penderita gagal ginjal yang cukup tinggi. Menurut data dari penefri (Persatuan Nefrologi Indonesia) diperkirakan ada 70.000 penderita gagal ginjal di Indonesia. Namun yang terdeteksi menderita gagal ginjal kronis tahap terminal dari mereka yang menjalani hemodialisa hanya sekitar 4.000 - 5.000 saja. Riskesdas tahun 2013 prevalensi penduduk Indonesia yang didiagnosis Gagal Ginjal Kroni oleh tenaga kesehatan ialah $0,2 \%$. Di RS Sumber Waras jumlah pasien yang rutin hemodialisa selalu meningkat, pada tahun 2016 yang rutin melakukan hemodialisa diunit hemodialisa berjumlah 51 pasien

Dialisa merupakan suatu proses yang digunakan untuk mengeluarkan cairan dan produk limbah dari dalam tubuh ketika ginjal tidak mampu melaksanakan proses tersebut. Tujuan dialisisa adalah mengeluarkan toksin atau zat racun dan kelebihan volume cairan untuk mencegah kerusakan permanen atau meyebabkan kematian. (Brunner \& Suddarth, 2002)

Penatalaksanan pasien GGK tahap akhir selain dilakukan tindakan hemodialisa, untuk jangka panjang juga diet dan pembatasan cairan. Untuk itu pasien perlu memahami tujuan dari tindakan tersebut agar tidak terjadi 
percepatan perburukan fungsi ginjal. Diet rendah protein akan mengurangi penumpukan limbah nitrogen dengan demikian meminimalkan gejala. (Brunner \& Suddarth, 2002).

Terapi diet hanya bersifat membantu memperlambat progresifitas gagal ginjal kronis. Pemberian suplemen seperti zat besi, asamfolat, kalsium, dan Vitamin D mungkin diperlukan. Pada pasien gagal ginjal kronis, focus terapi gizi bisa menghindari asupan elektrolit yang berlebihan dari makanan karena kadar elektrolit bisa meningkat akibat klirens renal yang menurun. (Hartono, 2006)

Diet yang bersifat membatasi akan merubah gaya hidup dan dirasakan pasien sebagai gangguan serta tidak disukai bagi banyak penderita gagal ginjal kronis. Jika pembatasan ini diabaikan (pelanggaran diet / tidak patuh), komplikasi yang dapat membawa kematian seperti hiperkalemia dan edema paru dapat terjadi. Pengaturan diet pada pasien gagal ginjal yang menjalani hemodialisis sedemikian kompleks, pengaturan diet tersebut sangat sukar untuk dipatuhi oleh pasien sehingga memberikan dampak terhadap status gizi dan kualitas hidup pasien.

Kepatuhan pada program kesehatan merupakan prilaku yang dapat di observasi dan dengan begitu dapat langsung diukur, kepatuhan itu sendiri adalah istilah yang dipakai untuk menjelaskan ketaatan atau pasrah pada tujuan yang telah ditentukan. Menurut Niven (2002), kepatuhan adalah sejauh mana perilaku pasien sesuai dengan ketentuan yang diberikan oleh professional kesehatan. Beberapavariabel yang mempengaruhitingkatkepatuhanmenurut Brunner \&Suddarth (2002) adalah demografi, penyakit, program pengobatan dan psikososial. Faktor -faktor yang mempengaruhi ketidakpatuhan dapat digolongkan menjadi empat bagian antara lain: pemahaman tentang intruksi, kualitas interaksi, isolasi social dari keluarga, keyakinan, sikap dan kepribadian. (Niven, 2002)

Secara umum menurut Syamsiah (2011), ketidak patuhan pasien dialysis meliputi 4 (empat) aspek yaitu: ketidakpatuhan mengikuti program Hemodialisa (0-32,3\%), ketidakpatuhan terhadap restriksi cairan (3.4\%$74 \%$ ) dan ketidakpatuhan mengikuti program diet (1.2\%-84\%). Maka dapat disimpulkan bahwa pengetahuan, pendidikan dan lama menjalani terapi hemodialisa penting dalam menjalani kepatuhan pengaturan asupan diet.

Berdasarkan hasil studi pendahuluan pada tanggal 31 Oktober 2015 di RS Sumber Waras, melalui wawancara langsung dengan 10 pasien gagal ginjal yang sedang menjalani hemodialisa, didapatkan 60\% pasien mengatakan tidak mengatur dietnya tiap hari, $40 \%$ pasien mengatur diet/makanannya sebaik mungkin. Sehingga terlihat bahwa kepatuhan pasien gagal ginjal kronis dalam pengaturan diet yang menjalani terapi hemodialisa masih sangat rendah.

Faktor - faktor yang dapat menjadi penyebab terjadinya ketidakpatuhan dalam melaksanakan pengaturan diet, antara lain: usia, jenis kelamin, dan pekerjaan, kurangnya pengetahuannya tentang pengaturan asupan diet, pendidikan pasien, lama menjalani hemodialisa, dan dukungan keluarga.

Sekitar 30\% pasien gagal ginjal kronis sering dirawatinap di RS SumberWaras Jakarta, dengan keluhan sesak, dan dilakukan hemodialisa di luar jadwal yang telah ditentukan. Selain itu terdapat peningkatan jumlah pasien GGK yang dilakukan hemodialisa di RS Sumber Waras, dengan latar belakang ini maka peneliti tertarik untuk mengetahui faktor-faktor yang berhubungan kepatuhan diet pada pasien GGK di Unit Hemodialisa RS SumberWaras. 


\section{METODE PENELITIAN}

Dalam penelitian ini, peneliti menggunakan jenis penelitian non eksperimen deskriptif analitik dengan rancangan cross sectional. Penelitian ini dilakukan di Rumah Sakit Sumber Waras pada bulan Juli-September 2016. Populasi pada penelitian ini adalah pasien GGK yang menjalani terapi hemodialisa di Unit Hemodialisa RS Sumber Waras dengan total sampling sebanyak 51 orang (data populasi diambil dari data jumlah pasien bulan Januari - Desember 2015). Variabel dalam penelitian ini kepatuhan pasien GGK sebagai variable independen. Metode pengumpulan data dilakukan dengan wawancara dan menggunakan instrument kuesioner. Variabel kepatuhan pasien menggunakan skala likert diukur melalui jawaban kuesioner, pernyataan yang diajukan sebanyak 8 pernyataan dengan 4 pilihan jawaban, setiap pernyataan memiliki skor 1 sampai 4; dengan kriteria: untuk jawaban selalu diberi skor 4, sering diberi skor 3, kadang-kadang diberi skor 2, dan tidak pernah diberi skor 1. Total skor maksimal adalah 32 dan total skor minimal adalah 8. Dikatakan patuh apabila mendapat skor> 20 dan dikatakan tidak patuh apabila mendapat skor $\leq 20$, dan untuk mengukur pengetahuan dengan menggunakan kuesioner yang terdiri dari sepuluh pertanyaan serta lamanya hemodialisa dikelompokan 2 yaitu kurang dari 6 bulan atau lebih dari 6 (enam) bulan.

\section{HASIL}

Penyajian hasil analisa dibagi menjadi dua yaitu analisa univariat dan analisa bivariat sebagaimana yang terurai dibawah ini.

Penyajian data pada analisis univariat disajikan dalam bentuk distribusi frekuensi atau jumlah proporsi atau presentase dari masing-masing kategori dan setiap variabel yang menjadi perhatian dalam penelitian ini.

\section{Analisis Univariat}

Tabel 1 menunjukan pasien gagal ginjal kronik di unit hemodialisa RS Sumber Waras tahun 2016 memiliki pendidikan dasar $56,9 \%$, lamanya menjalani hemodialisa (> 6 bulan) $74,5 \%$, pengetahuan kurang $49 \%$, dan $72,5 \%$ tidak patuh.

Karakteristik responden yang menjalani terapi hemodialisa berdasarkan pendidikan di RS Sumber Waras Tahun 2016, menunjukkan bahwa hamper sebagian besar responden berpendidikan dasar yaitu(56,9\%), berdasarkan lamanya menjalani hemodialisa di RS Sumber Waras Tahun 2016, menunjukkan lamanya menjalani hemodialisa (> 6 bulan), sebesar74,5\%. 
Analisis univariat pada penelitian ini disajikan sebagai berikut:

Tabel 1

Distribusi Frekuensi Karakteristik Responden Berdasarkan Pendidikan, Lamanya Menjalani Hemodialisa, Pengetahuan Dan Kepatuhan di Unit hemodialisa RS SumberWaras Tahun 2016

\begin{tabular}{lcc}
\hline Pendidikan & Frekuensi & Persentase $\mathbf{( \% )}$ \\
\hline Dasar & 29 & 56,9 \\
Tinggi & 22 & 43,1 \\
Total & 51 & 100 \\
\hline Lamanya Menjalani & & \\
Hemodialisa & & \\
\hline Lama & 38 & 74,5 \\
Baru & 13 & 25,5 \\
Total & 51 & 100 \\
\hline Pengetahuan & & \\
\hline Kurang & 25 & 49,0 \\
Cukup & 13 & 25,5 \\
Baik & 13 & 25,5 \\
Total & 51 & 100 \\
\hline Kepatuhan Diet & & \\
\hline TidakPatuh & 37 & 72,5 \\
Patuh & 14 & 27,5 \\
Total & 51 & 100 \\
\hline Sumber: Data Primer Diolah & &
\end{tabular}

Karakteristik responden hasil penelitian menunjukkan sebagian besar pasien GGK di unit hemodialisa RS Sumber Waras tahun 2016 memiliki pengetahuan yang kurang baik tentang kepatuhan diet yaitu (49,0\%) dan menunjukkan ketidakpatuhan dalam diet sebesar 72,5\%.

\section{Analisis Bivariat}

Analisa bivariat dilakukan untuk mengetahui atau melihat hubungan antara dua variabel, yaitu variable dependen (Kepatuhan diet pada pasien gagal ginjal kronik) dan variable independen (Pengetahuan, pendidikan dan lamanya menjalani terapi hemodialisa). Uji statistik yang digunakan pada penelitian ini adalah ujichi square, dengan derajat kepercayaan $95 \%$ pada alpha $\leq 0,05$. Analisis

Tabel 2 diatas menunjukkan ada hubungan yang bermakna antara pengetahuan dan lamanya menjalani hemodialisa dengan kepatuhan dengan nilai $\mathrm{p}<0,05$.

Pada table diatas dapat dilihat hasil uji statistic chi square didapatkan nilai p value: 0,006 . Hal ini membuktikan bahwa ada hubungan antara pengetahuan dengan kepatuhan diet pada pasien gagal ginjal kronis di unit hemodialisa RS Sumber Waras Tahun 2016

Berdasarkan hasil penelitian menunjukkan bahwa hamper seluruh responden yang tidak patuh diet pada pasien gagal ginjal kronik $(72,4,0 \%)$ pasien berpendidikan dasar hasil uji statistic chi square didapatkan nilai p value: 1,000 . 
Bivariate pada penelitian ini disajikan sebagai berikut:

Tabel 2

Hubungan Antara Pengetahuan Dengan Kepatuhan Diet Pada Pasien Gagal Ginjal Kronis Di Unit Hemodialisa RS Sumber Waras Tahun 2016

\begin{tabular}{|c|c|c|c|c|c|c|c|c|}
\hline \multirow{3}{*}{ Aspek } & \multirow{3}{*}{ Kriteria } & \multicolumn{4}{|c|}{$\begin{array}{c}\text { Kepatuhan Diet Pada Pasien Gagal } \\
\text { Ginjal Kronis }\end{array}$} & \multirow{3}{*}{ Total } & \multirow{3}{*}{$\begin{array}{c}\mathbf{P} \\
\text { Value }\end{array}$} & \multirow{3}{*}{$\begin{array}{l}\text { OR }(95 \% \\
\quad \text { CI })\end{array}$} \\
\hline & & \multicolumn{2}{|c|}{ Tidak Patuh } & \multicolumn{2}{|c|}{ Patuh } & & & \\
\hline & & $\mathbf{n}$ & $\%$ & $\mathbf{n}$ & $\%$ & & & \\
\hline \multirow{4}{*}{ Pengetahuan } & Kurang Baik & 21 & $84,00 \%$ & 4 & $16,00 \%$ & 25 & 0,006 & \\
\hline & Cukup & 11 & $84,62 \%$ & 2 & $15,38 \%$ & 13 & & \\
\hline & Baik & 5 & $38,46 \%$ & 8 & $61,54 \%$ & 13 & & \\
\hline & Total & 37 & $72,55 \%$ & 14 & $27,45 \%$ & 51 & & \\
\hline \multirow{3}{*}{ Pendidikan } & Pendidikan Dasar & 21 & $72,41 \%$ & 8 & $27,59 \%$ & 29 & 1 & \multirow{3}{*}{$\begin{array}{c}0,984 \\
(0,284- \\
3,410)\end{array}$} \\
\hline & Pendidikan Tinggi & 16 & $72,73 \%$ & 6 & $27,27 \%$ & 22 & & \\
\hline & Total & 37 & $72,55 \%$ & 14 & $27,45 \%$ & 51 & & \\
\hline \multirow{3}{*}{$\begin{array}{c}\text { Lama Menjalani } \\
\text { Terapi } \\
\text { Hemodialisa }\end{array}$} & Lama & 33 & $86,84 \%$ & 5 & $13,16 \%$ & 38 & 0,000 & \multirow{3}{*}{$\begin{array}{l}14,850 \\
(3,289- \\
67,039)\end{array}$} \\
\hline & Baru & 4 & $30,77 \%$ & 9 & $69,23 \%$ & 13 & & \\
\hline & Total & 37 & $72,55 \%$ & 14 & $27,45 \%$ & 51 & & \\
\hline
\end{tabular}

Sumber: Data Primer Diolah

Hal ini membuktikan bahwa tidak ada hubungan antara tingkat pendidikan dengan kepatuhan diet padapasien GGK di unit hemodialisa RS Sumber Waras Tahun 2016. Responden yang tidak patuh diet pada pasien gagal ginjal kronik $(72,5 \%)$ terbukti memiliki hubungan yang bermakna dengan lamanya pasien lama (> 6 bulan) menjalani terapi hemodialisa didapatkan nilai $\mathrm{p}$ value: 0,006 . Hal ini membuktikan bahwa ada hubungan antara pengetahuan dengan kepatuhan diet pada pasien gagal ginjal kronis di unit hemodialisa RS Sumber Waras Tahun 2016.

\section{PEMBAHASAN}

Tingkat pendidikan dapat meningkatkan kepatuhan, sepanjang bahwa pendidikan tersebut merupakan pedidikan yang aktif yang diperoleh secara mandiri, lewat tahapan-tahapan tertentu dalam Niven (2002). Hasil penelitian responden dengan berpendidikan dasar yaitu (56,9\%). Hasil penelitian ini sesuai dengan teori menurut Azwar A (2006) bahwa makin tinggi tingkat pendidikan seseorang, makin mudah menerima informasi sehingga makin banyak pula informasi yang dimiliki. Sebaliknya pendidikan yang kurang akan menghambat perkembangan sikap seseorang terhadap nilai-nilai yang baru diperkenalkan.

Individu dengan hemodialisa jangka panjang sering merasa khawatir akan kondisi sakitnya yang tidak dapat diramalkan dan gangguan dalam kehidupnya. Gaya hidup terencana dalam jangka waktu lama, yang berhubungan dengan terapi hemodialisa dan pembatasan asupan makan dan cairan pasein gagal ginjal kronik sering menghilangkan semangat hidup pasein sehingga dapat mempengaruhi kepatuhan pasien dalam therapy hemodialis aataupun dengan pembatasan asupan diet. (Brunner \& Suddarth, 2002) 
Dari hasil penelitian berdasarkan lamanya menjalani hemodialisa di RS Sumber WarasTahun 2016, menunjukkan lamanya menjalani hemodialisa (> 6 bulan), sebesar74,5\%. Hasil tersebut sesuai dengan penelitian oleh Kamerrer (2007) dimana pada pasien hemodialisa memperlihatkan perbedaan kepatuhan pada pasien yang sakit kurang dari 6 bulan dengan yang lebih dari 6 bulan. Semakin lama sakit yang diderita, maka resiko terjadi penurunan tingkat kepatuhan semakin tinggi. Hasil penelitian didapatkan responden memiliki pengetahuan yang kurang baik tentang kepatuhan diet 49,0\%. Hal ini sesuai teori menurut Hartono (2006) bahwa pengaturan pola makan atau diet pasien gagal ginjal kronik merupakan anjuran yang harus dipahami oleh setiap pasien gagal ginjal kronik. Pengaturan diet pada pasien gagal ginjal kronik sedemikian kompleks, pengaturan diet tersebut sangat sukar untuk dipahami oleh pasien sehingga memberikan dampak terhadap status gizi dan kondisi pasien.

Dari hasil wawancara penyebab ketidakpatuhan pasien GGK terhadap dietnya karena cuaca panas sehingga haus, makan diluar karena masih bekerja atau makan apa yang sudah disiapkan keluarga. Ketidakpatuhan bisa disebabkan ketidaktahuan Sebagai contoh masih terdapat pasien yang tidak tahu apa yang dimaksud dengan diet gagal ginjal kronik dengan terapi hemodialisa, tujuan dan manfaatnya. Diet pada pasien GGK sangat diperlukan hal ini bertujuan untuk mencegah defisiensi gizi serta mempertahankan dan memperbaiki status gizi, agar pasein dapat melakukan aktifitas normal. Menjaga keseimbangan cairan dan elektrolit serta menjaga agar akumulasi produk sisa metabolism tidak berlebihan (Kresnawan, 2004).

\section{Hubungan Antara Pengetahuan dengan Kepatuhan Diet pada Pasien Gagal Ginjal Kronis}

Teori model keyakinan kesehatan dimana perilaku kesehatan akan tumbuh dari keinginan individu untuk menghindari suatu penyakit dan kepercayaan bahwa tindakan kesehatan yang tersedia akan mencegah suatu penyakit. Pengetahuan merupakan hasil dari tahu dan ini terjadi setelah orang melakukan pengindraan terhadap suatu objek tertentu. Pengetahuan atau kognitif merupakan domain yang sangatpentinguntukterbentuknyatindakanseseorang (Notoatmodjo, 2006). MenurutSoenaryo (2004), pengetahuan merupakan salah satu faktor yang mempengaruhi seseorang untuk melakukan tindakan atau dengan kata lain pengetahuan mempengaruhi seseorang dalam perilaku. Hal ini dapat diartikan pengetahuan pasien tentang diet dan terapi hemodialisa dapat mempengaruhi kepatuhan diet dari hasil ujistatistik didapatkan nilai $\mathrm{p}$ value: 0,006 . Hal ini membuktikan bahwa ada hubungan antara pengetahuan dengan kepatuhan diet pada pasien Hal ini sejalan dengan hasil penelitian hasil penelitian Ismail (2011) tentang hubungan pendidikan, pengetahuan dan motivasi dengan kepatuhan diet pada pasien GGK di RSUP dr. Wahidin Sudiro Husodo Makasar.

\section{Hubungan Antara Pendidikan dengan Kepatuhan Diet pada Pasien Gagal Ginjal Kronis}

Pendidikan merupakan suatu proses pengubahan cara berfikir atau tingkah laku dengan cara pengajaran, penyuluhan dan penelitian. Pendidikan kesehatan tidak lepas dari proses belajar individu, kelompok masyarakat tidak tahu tentang nilai-nilai kesehatan menjadi tahu dan mampu mengatasai sendiri masalah-masalah kesehatan, sehingga kurangnya pendidikan seseorang dapat memberikan pengaruh dalam menentukan sikap, kepatuhan namun berdasarkan hasil penelitian menunjukkan 72,4,0\% responden berpendidikan dasar dan hasil ujistatistik chi square didapatkan nilai $\mathrm{p}$ value: 1,000 yang berarti pendidikan tidak mempengaruhi kepatuhan diet pada pasien gagal ginjal kronik diunit hemodialisa. Hasil ini tidak sejalan dengan penelitian Lita Kartika 
Sari (2009) menyebutkan bahwa adanya hubungan yang signifikan antara pendidikan dengan kepatuhan dalam pembatasan asupan cairan.

\section{Hubungan Antara Lamanya Menjalani Hemodialisa dengan Kepatuhan Diet pada Pasien Gagal Ginjal Kronis}

Terapi Hemodialisa merupakan terapi dalam upaya mempertahankan fungsi kehidupan pasien, hemodialisa yang adekuat dapat mempengaruhi kualitas hidup pasien, hemodilisa yang dilakukan akan memperbaiki kondisi fisik pasien merasa lebih baik dan lebih nyaman walaupun bersifat sementara untuk itu perlu dilakukan secara terus menerus, sehingga pada pasien berusaha untuk patuh pada jadwal hemodialisa. Hasil uji statistik dengan menggunakan uji chi square di dapatkan nilai $\mathrm{p}$ value: 0,000 berarti $\mathrm{p}<\alpha$ dimana nilai $\alpha: 0,05$ maka dapat disimpulkan bahwa H0 ditolak. Hal ini membuktikan bahwa ada hubungan antara lama menjalani terapi hemodialisa dengan kepatuhan diet pada pasien gagal ginjal kronis. Hasil penelitian ini tidak sejalan dengan penelitian Lita Kartikasari (2009) tentang faktor-faktor yang berhubungan dengan kepatuhan dalam pembatasan cairan pada klien gagal ginjal kronik yang menjalani terapi hemodialisa di RSUP Fatmawati Jakarta, menyebutkan bahwa belum cukup bukti untuk menyatakan adanya hubungan antara lama menjalani hemodialisa dengan kepatuhan dalam pembatasan cairan.

\section{KESIMPULAN}

Dari hasil penelitian ini dapat diketahui bahwa sebagian besar berpendidikan dasar (56,9\%), lama menjalani hemodialisa lebih dari 6 bulan $(74,8 \%)$ dan berpengetahuan kurang baik $(94,8 \%)$. Serta pasien gagal ginjal kronik dengan therapy hemodialisa tidak patuh terhadap diet. $(72,15 \%)$. Ada hubungan yang bermakna antara pengetahuan terhadap kepatuhan diet pada pasien gagal ginjal kronik, dan terdapat hubungan bermakna antara lamanya menjalani terapi hemodialisa terhadap kepatuhan diet pada pasien gagal ginjal kronis.

\section{REFERENSI}

1. Hadi, S., 2015. Hubungan Lama Menjalani Hemodialisis dengan Kepatuhan Pembatasan Cairan pada Pasien Gagal Ginjal Kronik di PKU Unit 2 Yogyakarta, Yogyakarta: s.n.

2. Hakiki, A., 2015. Analisa Faktor - Faktor yang Berhubungan Dengan Kepatuhan dalam Pembatasan Asupan Cairan di RS PKU Muhamammadiyah Yogyakarta, Yogyakarta: s.n.

3. Haryono, R., 2012. Keperawatan Medikal Bedah Sistem Perkemihan. Yogyakarta: Rapha Publishing.

4. Notoatmodjo, 2012. Promosi Kesehatan dan Perilaku Kesehatan. Jakarta: Rineka Cipta.

5. A. S. Price, M. W., 2006. Patofisiologi Konsep Klinis Proses Penyakit Alih Bahasa : dr. Brahm U. Jakarta: EGC.

6. Badan Penelitian dan Pengembangan Kesehatan Departemen Kesehatan Republik Indonesia, 2013. Riset Kesehatan Dasar, Jakarta: Departemen Kesehatan Republik Indonesia.

7. Ridlwan Kamaluddin, E. R., 2009. Analsis Faktor - Faktor yang Mempengaruhi Kepatuhan Asupan Cairan pada Pasien Gagal Ginjal Kronik dengan Hemodialisis di RSUD Prof. Dr. Margono Soekarjo Purwokerto. Jurnal Keperawatan Soedirman (The Soedirman Journal of Noursing), 4(1).

8. S.C. Smeltzer, B. B., 2008. Textbook of Medical Surgical Nursing. Philadelphia: Lipincott Wliiams \& Willkins. 
9. Sumilati \& Soleha, 2015. Hubungan Tingkat Pengetahuan dengan Kepatuhan Diet pada Pasien Gagal Ginjal Kronik yang DIlakukan Hemodialisis Reguler di Rumah Sakit Darmo Surabaya. Jurnal Ilmiah Kesehatan, 8(2), pp. 131-136.

10. Karundeng, Y., 2015. Hubungan Kepatuhan Pasien Gagal Ginjal Kronik dengan Keteraturan Tindakan Hemodialisa di BLU RSUP Prof. dr. R.D Kandou Manado. JUIPERDO, 4(1).

11. Comelia \& dkk, 2011. Penuntun Konseling Gizi. Jakarta: PT. Abadi.

12. Brunner \& Suddarth, 2002. Buku Ajar Keperawatan Medikal Bedah. Jakarta: EGC. 